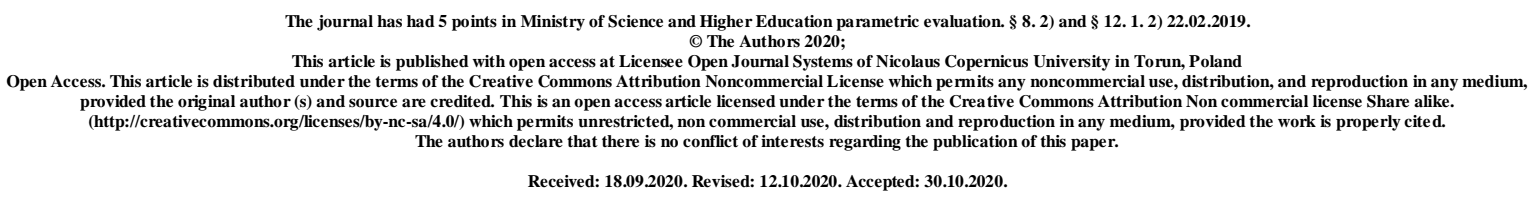

UDK 342.924

\title{
HISTORICAL ASPECTS OF THE DEVELOPMENT OF CUSTOMS CLEARANCE ON MARITIME TRANSPORT
}

\author{
Timur Dzhemlikhanov
}

\section{Technotorg LLC}

\begin{abstract}
The article is devoted to the study of the historiography of maritime transport and customs clearance. The historical aspects of the development of customs clearance in maritime transport are covered. The origin of shipbuilding and the development of navigation are analyzed, and it is indicated that in the process the customs for the transportation of goods through foreign territory were approved. The same customs in the form of duties were established in the courts. In practice, the duty in its economic essence served not so much as a tax as a levy, so it was paid not from the goods, but for the right of people to enter this territory.
\end{abstract}

Keywords: customs clearance; maritime transport; tax; duty; shipping; shipbuilding; territory; ports. 


\title{
ИСТОРИЧЕСКИЕ АСПЕКТЫ РАЗВИТИЯ ТАМОЖЕННОГО ОФОРМЛЕНИЯ НА МОРСКОМ ТРАНСПОРТЕ
}

\author{
Тимур Джемлиханов
}

\section{Общество с ограниченной ответственностью «Техноторг»}

\begin{abstract}
Аннотация
Статья посвящена исследованию историографии морского транспорта и таможенного оформления. Освещены, исторические аспекты развития таможенного оформления на морском транспорте. Проанализировано, зарождение судостроения и развитие мореплавания, при этом, указано, что в процессе утверждались обычаи за перевозка товаров через чужую территорию. Такие ж обычаи в виде пошлин устанавливались и на судах. Практически пошлина по своей экономической сути выполняла функцию не столько налога, сколько побора, потому платилось не из товара, а за право въезда людей на эту территорию.
\end{abstract}

Ключевые слова: таможенное оформление; морской транспорт; налог; пошлина; мореплавание; судостроение; территория; порты.

Statement of the problem. Ukraine - a Maritime state with a well-developed water transport infrastructure, ensuring the development of foreign and domestic trade and passenger traffic. It is located at the crossroads of Eastern Europe and the Mediterranean basin, bordering the Black and Azov seas, belonging to the basin of the Atlantic ocean. Out of the Black and Azov seas through the Bosporus, Dardanelles, Gibraltar and the Suez canal to the World's oceans allows Ukraine to use resources of the ocean for the needs of the economy and attribute it to the Maritime States, which according to international law, are the biggest perks. Network of commercial and fishing ports covers the coast of Ukraine from the port of Izmail in the West to Mariupol in the East. Ports of Black and Azov seas are carried out economic and trade ties with almost all countries of the world. After gaining independence, Ukraine have in the state, the Department of internal sea waters and the territorial sea. According to the norms of the UN Convention on the law of the Sea (1982), she is entitled to the exclusive (Maritime) economic zone, which gives the opportunity to develop foreign trade $[1]$. 
The relevance of the research topic. History of Ukraine is recognized for many researchers the object of special attention and a source of constant debate. Among the complex problems of the historical past of Ukraine are of great interest the development of the Maritime spaces of the South, construction of commercial and military fleets, creation of safe conditions of navigation for sea and river transport. The industrial revolution that happened in Ukraine over 40-80 years of the XIX century, persistently put forward the task of creating a branched transport infrastructure, where an important place was given that sea transportation. In many respects depended on the livelihoods of major coastal regions of Ukraine, where fruitfully linked customs clearance [2].

The state of research. Great attention in researches of scientists in the field of customs and marine transport paid: Yes.In. Dodin, E. Be. Khachaturov, A. S. Trofimov, V. J. Nastyukov and others. They paid the value of scientific disclosure issues with respect to customs clearance, customs procedures in Maritime transport, but out of sight itself remains a historic feature of the relationship of Maritime transport and customs clearance, which is very important and requires research.

The purpose of this article is to study the historical aspects of the development of customs clearance for sea transport.

Presentation of the basic material. Even in prehistoric times man began to float on water. Creating means for movement through the water traces its history back to ancient times. The first such funds appeared before the Neolithic period (New stone age), when it was created stone tools and the man had the opportunity to work wood. The raft associated with a $\log$, and then the boat hollowed from a tree trunk, were the first structures created by primitive people to move through the water.

Tree - the most ancient building material for thousands of years served humans to build ships. This is evidenced by the hollowed-out oak forty centuries ago Chelny. Extant oak boat was built about four thousand years ago, and was found on the coast of lake Ladoga, lying in the southern bug is about 2,500 years old found in excavations in the city of Izyum in the Ukraine. The length of the boat ranged from 3.5 to $8.5 \mathrm{~m}$ with an average width of $0.7-1.2$ m. To replace a simple craft came more complex, leather-covered boats, driven by the muscular force of the person using the paddles [3].

The nature of rivers, their tributaries where the water is shallow, mnogonogie lakes, rapids, and frequent transportation to vodorazdela - all this determined the design and the device ships, their size, draught and methods of the movement. The principle of using the courts for one of navigation or flight and the need to pass on the shallow tributaries left their 
mark on the shape and hull design. Type of rafting boats were made with a rectangular cross section dealspot and vertical stepname. Despite the great similarity in the shape and dimensions of the buildings, they had different local names. From a large number of vessel types had a wide distribution in Russia known for: boats, planes, and uchani, pavodok, domanik etc [4].

Put - court-of odnodnevki, which was addressing the Board Board. Board side plating in the grooves connected "carvel planking" so that their edges densely adjoined to each other, creating the smooth surface of the boards. Had held high and aft. Struga is a small, flatbottomed nishikomori court with a very shallow draft. Were made without cartridges and ammunition, greatly increased in size. Naboen planes of these vessels differed from the Board because the Board side plating should be a "cover". Uchani - planked flat-bottomed vessels. Was common until the seventeenth century. almost all river basins. These vessels are used not only for transportation and unloading of larger ships [5].

The construction of the rowing ships began in Ancient Babylon (around the XVII century. to n. e), for a long time they were the only means of communication at sea. They have been trading expeditions, military campaigns. Increase the speed of ships attempted to reach the increasing number of rowers, which placed sometimes in several tiers. Oremi, bremi and trireme, the ship on which the rowers sat in one, two and three circles respectively. However, even trireme moving at the speed of $12-13 \mathrm{~km} / \mathrm{h}$. Ship in those days, designed for combat operations and for trading, were built differently. Fast were military ships, they were built narrow and long to accommodate the bigger rowers. The main weapon of warships was the battering RAM - a log, sometimes wrought iron or metal casting, located in the nose. On the deck of the ships (Pentre) - installed catapults. But the merchant ships were broad and capacious (their capacity reached 300 tons) [3].

For the development of the shipbuilding industry has done much the Phoenicians who inhabited the Eastern coast of the Mediterranean sea. They were not only good sailors but also great shipbuilders. Phoenician wooden ship is characterized by a large number of different patterns. On the nose of the ship was often depicted with a horse's head - the emblem of the Phoenician people [5].

The beginning of shipbuilding and navigation in the Russian Empire stretches back to the ancient times. Archaeological finds on the p the southern bug on the coast of lake Ladoga and other places indicate that the ancient Slavs more than 3,000 years ago, built the boat odnodnevki, boats made of twigs, bark or leather. In their place came more complex and seaworthy boat (tours), which they sailed across the Black sea to Constantinople. In the XII 
century and became widespread in Zaporizhia "the Seagull", armed with oars and a small sail. These speed boats that can seat up to 70 Cossacks were military ships, and made military campaigns [6].

With the development of science and technology has gradually increased the size of vessels and improved sailing rig, created new navigational instruments, ship equipment. However, rowing warships, which later were called galleys, and participated in sea battles relatively recently - about 200-300 years ago. Permanent trading and military confrontation between the great Maritime powers (Britain, Spain, Portugal, France, Byzantium), who competed for supremacy not only in sea but also in the world ocean, gave an impetus to the rapid development of shipbuilding. Wide use has become galleys and Galleons. In the galleys, were catapults and other projectile machines, the soldiers were armed with "Greek fire", arrows, and later guns. Then replace the arms came the artillery. In the bow under the elevated deck in the middle, on course, there was a gun called curseyou and two small guns on either side of it. In the galleys, as a subsidiary driving means has set sail. The first sailing merchant ships appeared in Ancient Egypt about 3000 years BC [3].

In the era of Great geographical discoveries, the most widely Caravel - the three or four mast ship with a high stern, low nose and a complex system of sails. The development of trade between countries, and therefore the navigation required to increase capacity and speed of ships, improving their seaworthiness and increase combat power. So there was a fast Galleon, flute, Pasi, boats and then frigates - transogram the ships with two gun decks. Their speed reached 10 knots $(18.5 \mathrm{~km} / \mathrm{h})$. Dooglav sailing ships with square sails called Origami. Barca had three or four masts: the mast aft carrying the slant of the sails, and the rest of the mast - straight. In XVII century the basis of military fleets become a line of the court. The term "battleship" came in connection with the emergence of new tactics of naval warfare.In battle, ships sought to line up in a row or line so that during their volley to be returned to the enemy sideways, and during his volley - aft. The fact is that the greatest damage to enemy ships was inflicted by a simultaneous volley of onboard guns. The main type of merchant sailing vessel in the XV-XVI centuries. there was a schooner with two or three or more masts and oblique sails. Schooners were considered the most economical vessels, as the management of oblique sailing weapons was easily handled by a relatively small team. However, these vessels were unstable [5].

The era of sailing ships ended in the early nineteenth century. In 1807, the American engineer Robert Fulton was built paddle steamer "Claremont", which is considered the world's first river steamer. It was installed made in England D. watt steam engine with a 
capacity of $21 \mathrm{~K}$. S. $(15,4 \mathrm{~kW})$. First voyage the steamer made for the city of Hudson at a speed of about 4.5 knots $(8.5 \mathrm{~km} / \mathrm{h})[3]$.

In 1815, at the Admiralty shipyard in St. Petersburg was built world's first naval steamship, which was intended for the line St. Petersburg-Kronstadt. He was a wheel with wooden case. The power of his steam engine equal to 4 K. S. $(2.9 \mathrm{~kW})$, speed 5 knots $(9 \mathrm{~km} /$ h).

In the first half of the nineteenth century. to replace wooden structures come iron. In 1834 there was a crisis in shipbuilders relative to iron as a shipbuilding material. From the time of "iron shipbuilding," spreading wider and wider until the mid-nineteenth century. implemented unconditionally [6].

In the late XIX early XX centuries. world trade continues to be a major factor in the successful development of not only the economy but also the entire state in General, the level of prosperity of its citizens and the position in geopolitics. At the same time more and more begins to intensify political, economic and military confrontation between the highly developed States. There was a struggle for colonies, new territories, material and human resources that ultimately led to military conflicts (I, II World war). This gave impetus for the rapid development of a morekhozyaystvenny complex. Large-scale construction works of military and commercial ships with high military equipment and navigation system [7].

The second half of the XIX century. marked a new progressive change - for the construction of vessels are beginning to use steel. The development of the shipbuilding industry contributed to the further improvement and increase the power of marine steam machinery, the creation of more efficient steam turbines and internal combustion engines. The use of steam turbines on ships began in 1901 in England and it is widely used on large ocean vessels and military ships [8].

The beginning of active development of civil marine shipbuilding can be considered the 50-ies of the XIX century. It was the result of deprivation of the right to build warships on the Black sea after defeat in the Crimean war of 1853-1856, the Government has taken a number of measures aimed at organizing commercial navigation, for the use of merchant ships for military purposes in case of war [6].

Water transport is of great importance for the world economy with its vast river, sea, ocean waterways and sea coasts nesmirne length. Marine vessels - the main means of transport in world trade. The demand for ships is highly dependent on processes occurring in the economy. Shipbuilding industry, being one of the most important sectors of the economy 
and with the scientific-technical and production potential, affect many other related industries and on the economy overall, and its defense and political situation in the world [9].

The history of the development of the customs system began when the cities of the black sea began to recover taxes for the movement of goods through foreign territory. With the emergence of the Scythian state in the beginning of VII century. to H. E. the customs and tariff relations received a new impetus in connection with the establishment of trade relations with the Scythians of Olbia, Chersonesos and other cities. Traditional goods trade of the Scythians with the Greek colonies on the black sea coast for many years was grain, furs, honey, etc. which were transported by the courts [10].

With the advent and development of Kievan Rus (IX-XII centuries), where the main source of funding was the payment of tribute, fee for litigation, fines and duties, customstariff relations entered character consistency. Therefore, most researchers of customs relations are inclined to believe that the germ the customs system in Ukraine appeared in the period. Overseas trade was the basis of the economic system of Kievan Rus, as one of the world's major trade flows "from the Varangians to the Greeks" passed through Kiev on the Dnieper, crossed the Black sea and ended in Constantinople center of trade. One of the first transactions made by Prince Oleg, was an agreement with Byzantium (911p.), for some merchants from Kievan Rus was created very favorable conditions: "... buy, for them hath need without paying myta anything the same." Thus, in Kievan Rus duty meant the tax is paid for the carriage of goods, transhumance across the borders of certain territories. There was cleaned a "dry" - for the land carriage of goods and "water" - for the carriage of goods by water [11].

The concept of customs dealt with the customs yards, catching for the collection of tamgas or duties. Customs certificate allows the person, the community and the monastery to enter on its behalf the bidding. So, customs or the customs courts in Kievan Rus was one of the public authorities of the state. Their main functions were: applying the mark on goods (and thus the state took responsibility for the quality of goods admitted to public trading); the levy for the admission of the product to sell to the domestic market; implementation of customs control over goods received from abroad and goods that are exported abroad. The same customs procedure occurred on ships coming in with goods to the ports. Almost duty in its economic essence acted not so much tax, how much exaction, for he paid not with goods, but with people for the right of entry to the territory.

The main type of travel duty was the assessment and payment of tax for the transportation of goods across a certain area. That was on a cart or boat, levy Golovina from 
0.5 to 6 money in different areas. People accompanying the goods, and sometimes going Kostka - the money of soul. When you return to the merchant with his people after the sale of goods are occasionally levied a kind of Golovina - kolaci 0.5 money per person. Depending on the size of the fees in yards have any kind of myta - planted. If the merchant toured the customs house (collateral) in order to evade payment of duty, was charged double the penalty from the cart - prometni and merchant as individuals - extra fine (commandment) [12].

The conquest of the land of Kievan Rus, the Tatar-Mongols led to the rooting of the word "Tamga", which means in Turkic peoples sign, stamp, put down on the property, which belonged to the family. Getting Khan's labels were accompanied by the fee, which was called in Russian Tamga. So soon were called duties, which are levied when trading in the markets and fairs. From the word "Tamga" was formed the verb "tamit", that is, to impose a product fee, and the place where the goods "family", became known as the customs (custom) [10].

The Ukrainian-Lithuanian and Polish day period of its statehood, Ukraine had on its territory in accordance with the subordination of existing customs legislation of Lithuania or Poland. Customs legislation of Lithuania was characterized by the presence of a large number of customs rates changed frequently and harsh sanctions against those who tried to circumvent customs posts, among which stood out in importance to Kiev, Chernigov, Chernobyl. Thus, in Chernihiv tax rate in the period was 2 back of the pack and product 3 the money with a cart, in Kiev, the duty was much higher - 30 of the money from the cart. The development of trade relations were hampered by the numerous domestic duties: "to wash" (bringing goods to sell or money to purchase goods); "turnout" (notice of intent to implement goods); "welcoming" (for office lease); "weight" (in determining the weight of the product). Internal customs duties were levied on all imported on the sale of goods. This rule did not apply to the owner of the essential commodities. In some cases, special golovnye diplomas were exempted from paying the fees, the persons of the clergy, the monasteries, the inhabitants of the new towns and certain areas, and people who rendered services to the state or Principality [11].

With the beginning of the First world war Ukrainian lands that were part of the warring empires, ceased to customs operations that are typical for peace. Their recovery occurred during the revival of Ukrainian statehood, the main attribute of which became the basis of an independent customs Department [13].

Temporary customs supervision prior to the introduction of the new customs Statute was carried out according to the requirements of the "Customs Statute" and other normative acts issued before October 27, 1917. as well as the General customs tariff of 1903. and Treaty 
agreements between Russia, Germany and Austro-Hungary, 1894, 1904, 1906. Customs operations were limited to border clearance of passengers with their baggage, among which the payable fee, but not in the presentation, was produced (without branding) after deduction of charges: a welcome to the review of all foreign cargo and mail arriving from abroad and diverted in transit to Odesa, Kyiv or Kharkov [14].

In the "Project of the Government Commission on the development of the Constitution of the Ukrainian State," noted that "all international trade and customs conditions, which impose other burdens on the state or on citizens of the state... shall take effect only with the consent of the State Parliament". Later, the idea about the necessity of state control over the customs system of Ukraine is reflected in the draft Constitution of the UNR, the tenth paragraph which noted that "the competence of the Federal State Organizations are the following: "...the customs and quarantine business, warehouses...".

The issues of organization of customs Affairs of Ukraine after the coup in 1918 were decided by the government, to strengthen the financial base of the country has created within the Ministry of Finance Department of customs fees. According to the decision of Hetman Pavlo Skoropadsky was organized Corps of border guards, which has been entrusted with not only functions of border protection of Ukraine, but also separate customs functions. During this period an agreement was concluded between Ukraine and Russia, according to which at the customs border between the States began to operate the customs stations of the Kharkiv customs [10].

The government that existed in the brief period of Ukrainian statehood, with a deep understanding about the problem of creation of the customs system, but for projects they do not have enough time.

Since the occupation of Ukraine in June 1919, Denikin's army, all state bodies, including customs, institutions subordinated to the Special meeting with the chief. In 19181920 pp., when almost the entire territory of Ukraine the fighting unfolded, international trade was virtually stopped. Under these conditions, the existence of the customs institutions have lost all meaning, recovery occurred already in the Soviet Ukraine.

The customs sector is a component of foreign policy and foreign economic activities of any state including Ukraine. In customs matters Ukraine follows recognized in international relations systems of classification and coding of goods, the unified form of declaring of export and import of goods for the marine industry, customs information, and other international norms and standards [11]. 
Conclusion. The analysis of customs relations in maritime transport, in terms of classification of features, distinguishes their various distribution, but is related to a similar direction - movement across the customs border. Therefore, being a complex branch of law, customs law, in its content, is directly related to other branches of law, thereby determining the regulation of customs relations by the rules of other branches of law.

In view of the above, we can conclude that with the emergence of trade relations and the development of Kievan Rus, the first sources of funding appeared: payment of tribute, court fees, fines and duties. Then the customs and tariff relations became systematic. The organization of customs affairs in Ukraine was first resolved in 1918, however, customs affairs came into force in Ukraine during the Soviet era and became part of the foreign policy and foreign economic activity of the state.

\section{References:}

1. Kharakterystyka suchasnykh vntazhopotokiv v Ukraini i prohnoz yikh rozvytku: URL: http//www.expert.kiev.ua/ua/works-catalogue/30-nashi-raboty/ua/

2. Finansy sudnobudivnykh pidpryiemstv: monohrafiia: Mykolaiv. NUK, 2012. 234s.

3. Vynyknennia sudnobuduvannia ta epokha vitrylnoho flotu:URL: http://bukvar.su/istorija/162444- Istoriya-vozniknove-niya-sudostroeniya.html

4. Shlykhter S. B. Heohrafyia myrovoi transportnoi systemi. Vzaymodeistvye transporta u terrytoryalnikh system khoziaistva: Yzd-vo Moskovskoho hos. un-ta, 1995. 101 S.

5. Istoriia vynyknennia sudnobuduvannia:URL: http://ukrbukva.net/4905Istoriya-vozniknoveniya-sudostroeniya.html

6. Sudostroenye Rosyy Azyzov: URL: http://www.refu.ru/refs/81/28046/1.html

7. Horlov A. P. Pytannia pravovoho rehuliuvannia naukovo-tekhnichnoho suprovodzhennia proektuvannia i budivnytstva obiektiv morskoi tekhniky $\mathrm{v}$ umovakh intehratsii pidpryiemstv sudnobuduvannia:Sudokhodstvo, 2001. № 5. S. 24-26.

8. Klochko V. Hlobalizatsiia ta yii vplyv na krainy z perekhidnoiu ekonomikoiu: Ekonomika Ukrainy, 2001. № 10. S. 51-58.

9. Hlobalyzatsyia myrovoi ekonomyky: URL: http:// www.grandars. ru/college/sociologiya/globa lizaciya. Html

10. Chentsov V.V. Mytne pravo Ukrainy: navchalnyi posibnyk: Istyna, 2008. $328 \mathrm{~s}$ 
11. Hrebelnyk O.P. Mytne rehuliuvannia zovnishnoekonomichnoi diialnosti: Tsentr navchalnoi literatury, 2005. 696s.

12. Ehorov A.B. Entsyklopedyia tamozhennoho dela: META,1996. 424s.

13. Kovalevskyi V. V. Rozmishchennia produktyvnykh syl: pidruchnyk: Znannia, 2001. $353 \mathrm{~s}$.

14. Alysov N. V. Ekonomycheskaia y sotsyalnaia heohrafyia myra (obshchyi obzor): uchebnyk dlia vuzov: Hardaryky, 2003. 704 s. 